\title{
Carbonate deposition and facies distribution in a central Michigan marl lake
}

\author{
DAVID H. MURPHY \& BRUCE H. WILKINSON Department of Geology and Mineralogy, The \\ University of Michigan, Ann Arbor, Michigan 48109, U.S.A.
}

\begin{abstract}
Relatively pure lacustrine carbonates referred to as marl are being deposited in Littlefield Lake, central Michigan, a hard-water lake with little terrigenous clastic influx. Thick accumulations of marl form both progradational marl benches along lake margins, and islands or lakemounts in the lake centre. Marl benches develop flat platforms up to $20 \mathrm{~m}$ wide in very shallow water and steeply inclined slopes, up to $30^{\circ}$, extending into deep water. The flat landward platform is frequently covered by algal pisoliths while the upper portion of the lakeward-sloping bottom is overgrown by Chara which in the summertime becomes thickly encrusted with low-magnesian calcite. Marl islands are flat-topped features that formed over relict highs on Pleistocene drift which underlies the lake basin. These are fringed by marl benches identical to those found along lake margins. Marl benches are composed of four units: two thin facies deposited on the shallow-water bench platform and two thicker faces deposited on the bench slope developed in moderate water depths. These in turn overlie a fifth facies deposited in deep water. A coarsening-upward sequence is developed in these sediments as a result of both mechanical sorting, and primary production of carbonate sand and gravel in shallow water. In addition to facies sequences and size grading, trends upsection of increasing carbonate content and decreasing insoluble content may serve to identify temperate-region lacustrine carbonate deposits in the rock record.
\end{abstract}

\section{INTRODUCTION}

The ability to interpret ancient sedimentary systems has increased greatly over the past 25 years. Excellent facies models now exist for many sedimentary environments, while the variation among models is reasonably well known for a few of these. Several systems, however, are more difficult to interpret in the rock record owing to a lack of data on modern analogues. The geometry and lithology of component facies within lacustrine systems in general, and calcareous lacustrine systems in particular, have received little attention.

Carbonate deposition in lakes occurs under several different sets of circumstances. Relatively shallow lakes in arid and semi-arid settings deposit carbonate primarily through evaporation. Limesione deposited in these settings is almost always impure, containing significant quantities of clay, and is usually associated with stromatolitic structures, dolomite, and

0037-0746/80/0400-0123\$02.00

(C) 1980 International Association of Sedimentologists more evaporitic minerals such as gypsum, halite, and in some cases more bittern salts. The most extensively studied sequence which may represent this type of depositional environment is the Green River Formation in Wyoming, Colorado, and Utah. These Eocene units, at least in part, reflect deposition in a relatively shallow playa setting (Eugster \& Surdam, 1973; Wolf bauer \& Surdam, 1974; Eugster \& Hardie, 1975; Surdam \& Wolfbauer, 1975). Numerous other late Tertiary and Quaternary sequences of the Western United States fit this model as well (Feth, 1964).

A second type of lacustrine system in which signifcant quantities of carbonate are deposited occurs in temperate regions. These systems occur as numerous hard-water lakes throughout the northern portion of the western United States. Marl lakes in this region were first examined with regard to their importance as a source of lime for cement manufacture. Blatchley \& Ashley (1900) suggested that the major processes of carbonate precipitation were 
physiochemical. They found that many Indiana lakes were fed by subaqueous springs releasing groundwater which had percolated through calcareous glacial drift. This water was assumed to be saturated with calcite and upon release into the lake precipitated calcite as a result of $\mathrm{CO}_{2}$ degassing. Davis (1900, 1901, 1903) concluded that Chara was the major agent of calcite precipitation in marl lakes. $\mathrm{He}$ found that Chara which thickly covered bench slopes was heavily encrusted with calcium carbonate. Since marl in these lakes contains many of these encrustations, he concluded that marl accumulation occurs primarily as a result of the breakup of characean skeletons. Pollock (1918) considered cyanophytes to be the chief calcite precipitating agent in marl lakes. In Michigan lakes he found extensive marl platforms covered only with bluegreen algal pisoliths, and argued that their disintegration produced the underlying thick marl deposits.

Kindle $(1927,1929)$ was an advocate of physiochemical precipitation. He showed that marl lakes do not occur above $1500 \mathrm{~m}$ in elevation, or north of $60^{\circ}$ latitude. Only below these limits does thermal stratification become well developed in lakes. A marl lake must develop a thin surface zone of warm water which becomes saturated with calcium carbonate in order for calcite deposition to occur. Wetzel (1960) reviews mechanisms involving biogenically induced calcite precipitation of encrustations on lake hydrophytes. In marl lakes the dominant form of carbon available for photosynthesis is the bicarbonate ion. During photosynthesis bicarbonate utilization produces a micro-environment of higher $\mathrm{pH}$ immediately surrounding the hydrophyte which in turn induces precipitation of calcium carbonate. Both Terlecky (1974) and Brunskill (1968) have reported on studies of calcite precipitation in marl lakes in New York. They concluded that the dominant depositional mechanism in marl lakes is physiochemical precipitation of calcite.

Littlefield Lake was studied in an attempt to assess the thickness and distribution of component facies within a temperate-region lacustrine carbonate system, and to develop a predictive model which could be utilized in the identification of similar systems in the stratigraphic record. This lake was chosen for several reasons: (1) it has been relatively unmodified by human development, (2) numerous data on the thickness of marl deposits have been reported by Davis (1903), and (3) it is one of the most spectacular examples of a carbonate-precipitat- ing lake we have encountered in this region. Marl deposits in Littlefield Lake are extremely pure calcium carbonate and, as a result, occur as wide offwhite rims around the lake.

Littlefield Lake is located in Isabella County in the central portion of the southern peninsula of Michigan. It is underlain by glacial outwash and lies between the second and third moraines of the Saginaw Lobe. The total thickness of glacial drift is about $180 \mathrm{~m}$, and contains many till and outwash gravel horizons; all of the surface till is calcareous (Kerr \& Trull, 1928).

\section{LAKE BASIN CHARACTERISTICS}

\section{Basin morphology}

The Littlefield Lake basin is composed of several coalescing kettle-holes, the largest of which is over $20 \mathrm{~m}$ deep (Fig. 1). The lake has an area of $0.7 \mathrm{~km}^{2}$ (Marsh \& Borton, 1974). The thermocline lies between 7 and $10 \mathrm{~m}$ in late summer; at this time the epilimnion is about $20^{\circ} \mathrm{C}$ and has a $\mathrm{pH}$ of 8.2 , while the hypolimnion is about $9^{\circ} \mathrm{C}$ and has a $\mathrm{pH}$ of $7 \cdot 4$ (Institute for Fisheries Research, 1950). Methyl orange alkalinity averages 155 p.p.m., indicating this is a 'hard-water lake' employing the classification scheme of Hooper (1956).

The lake is fed by numerous springs and by three small streams which enter two daughter lakes at the northwestern end (Fig. 1). The small streams are fed by springs from the surrounding hills (Davis, 1903). This water is saturated with calcium carbonate as a result of groundwater percolation through the surrounding calcareous glacial drift. The outlet also flows out of a daughter lake at the southeastern end. Terrigenous debris carried by the three small streams are deposited as Gilbert deltas as they enter the smaller basins. As a result, the main lake basin receives little terrigenous clastic influx from these fluvial sources. There is, however, a smalt aeolian input from exposures of glacial drift surrounding the lake.

Marl deposits are composed of low-magnesium calcite $\left(2-3 \% \quad \mathrm{MgCO}_{3}\right)$ with minor amounts of quartz, plagioclase, potassium feldspar, pyrite, and occasionally illite and chlorite. The small amount of aragonite occurs only as mollusc shells. Thick deposits of marl form shallow flat-topped structures called benches around the entire lake perimeter, and lakemounts or islands in the basin centre. The marl bench can be divided into two distinct portions: (1) a 


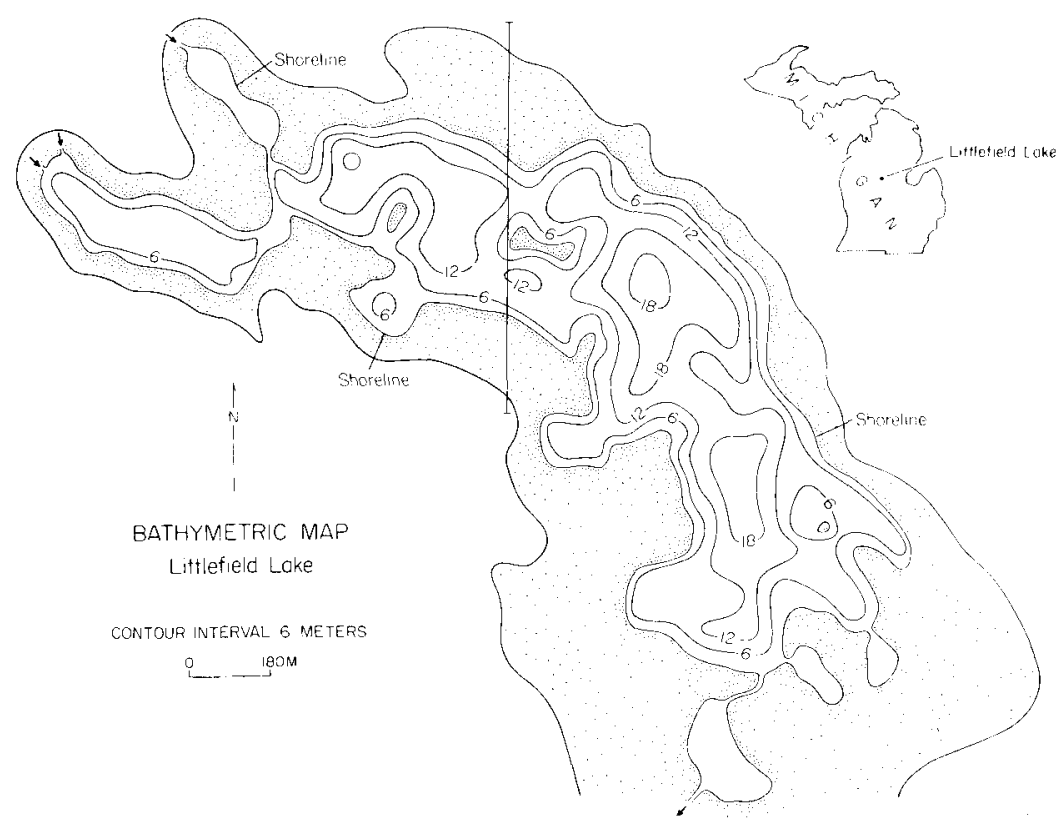

Fig. 1. Bathymetric and geological map of Littlefield Lake. The stippled area is underlain by Holocene peat and marl which in turn is underlain and surrounded by glacial drift. The north-south line of section is Fig. 4. Arrows designate the position of inlets and outlets. Bathymetry modified from Institute for Fisheries Research (1950).

flat landward bench platform, and (2) a steep bench slope inclined lakeward. The bench platform is inclined basinward at an angle of about $2^{\circ}$, lies in water depths of less than $1.5 \mathrm{~m}$, and is nearly devoid of macrophytes. Instead, the surface is covered mainly by blue-green algal pisoliths and carbonate sand, and some organic debris. In Littlefield Lake, the width of the bench platform ranges from 5 to $20 \mathrm{~m}$. On the outer $2 \mathrm{~m}$, the lakeward dip of the surface increases greatly until it slopes into deep water at angles up to $30^{\circ}$. The bench slope is covered by a thick growth of the chlorophyte, Chara, which in the summertime becomes thickly encrusted with calcite.

The lakemounts or islands are developed over relict highs on the Pleistocene outwash surface. In Littlefield Lake there are three such lakemounts. Under all three, the Pleistocene surface is $8 \mathrm{~m}$ below lake level. Lakemounts commonly occur as barely emergent flat-topped islands fringed by benches identical to those found along the main lake margins. These islands are elevated only about $5 \mathrm{~cm}$ above the lake and have a dense cover of low shrubs.

\section{Sediment thickness and distribution}

In 1903 C. A. Davis published a study of Littlefield
Lake which included numerous data on the thickness of marl and peat deposits. His data in combination with thickness data from this study were used to produce net marl and net peat isopach maps (Figs 2 and 3). Data utilized in the construction of these isopachs were supplemented by the use of two preliminary maps. The first was a topographic map on top of the Pleistocene drift constructed from U.S.G.S. topography of surrounding areas, and true elevations on drift underlying Holocene units from this and Davis' (1903) study. The second was a topographic map on top of both Pleistocene and Holocene units based on U.S.G.S. topography and a bathymetric map of Littlefield Lake. By 'subtracting' the two, a net Holocene sediment isopach was derived, and subsequently adjusted with true thickness data. This method allows for reasonable estimates of thickness of Holocene sediment in areas of low data density. The net marl isopach (Fig. 2) shows that the thickest accumulations directly underlie benches along the lake margin and lakemounts in the basin centre. Deeper portions of the lake basin are underlain by thinner marl deposits.

As a marl bench progrades basinward and as the bench platform becomes subaerially exposed it is quickly colonized by terrestrial plants. These areas 


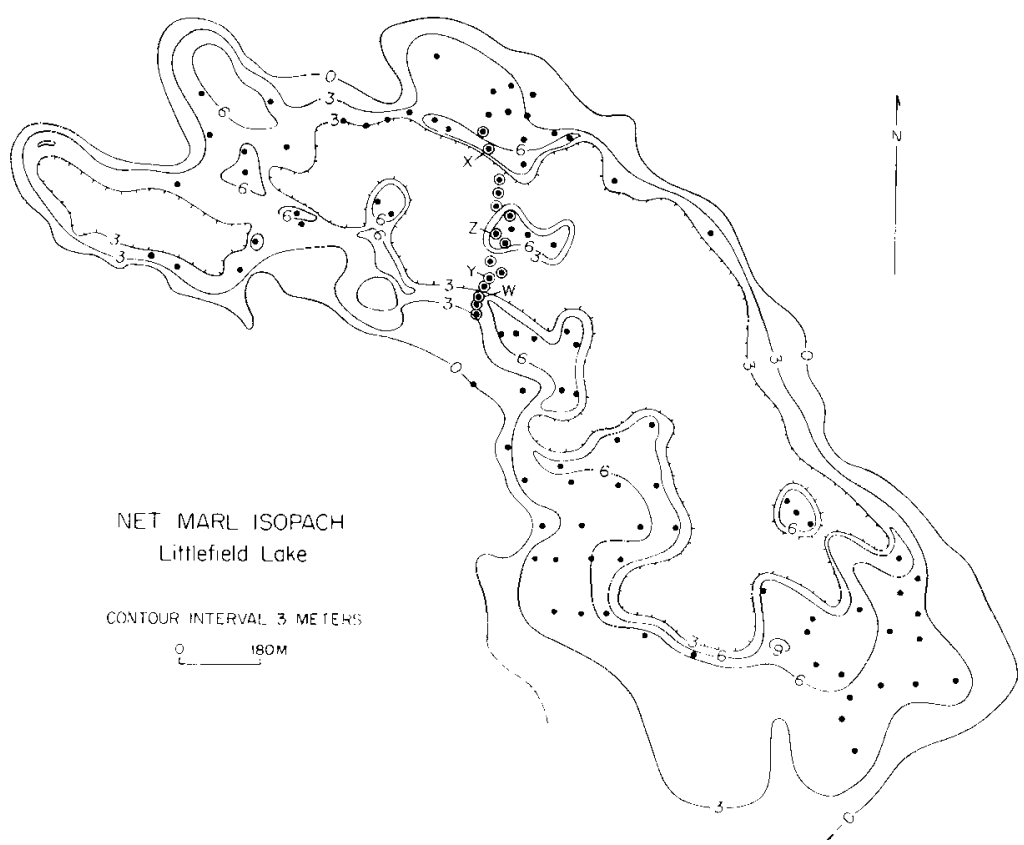

Fig. 2. Net marl isopach map of Littlefield Lake, contoured utilizing data from Davis (1903) shown as solid points, and from this study shown as circled points. Note the thicker marl accumulations under lake-margin benches and basincentre lakemounts. Cores $\mathrm{W}, \mathrm{X}, \mathrm{Y}$, and $\mathrm{Z}$ are identified in later figures.

develop a swampy character and peat accumulates with time. The net peat isopach (Fig. 3) shows decreasing peat thickness toward the present lake edge reflecting thicker peat accumulation on older exposed surfaces and the progradational nature of both the peat and the underlying marl bench sequence.

Relationships between the physiographical features and organic and carbonate facies within the Littlefield Lake system can further be seen in Fig. 4, a north-south cross-section through the basin constructed from cores taken through the Holocene sequence and from Figs 2 and 3. This section again shows the characteristic thickening of marl along lake margins and under lakemounts, as well as thicker peat accumulation on older, now-exposed bench platforms. Sedimentation takes place primarily through carbonate generation in surface waters, and carbonate deposition on lakeward inclined bench slopes. Thinner sediment accumulation in deeper water areas is probably a function of greater rates of carbonate precipitation near shore and higher rates of carbonate dissolution in the deeper, cooler waters of the hypolimnion.

\section{LITHOLOGY OF SEDIMENTS}

Over $50 \mathrm{~m}$ of $5 \mathrm{~cm}$ core was taken at fifteen stations along a north-south line across the Littlefield Lake complex to assess the thickness and distribution of component facies within this lacustrine carbonate system (Fig. 4). Each core was split, photographed, described, and sampled at $30 \mathrm{~cm}$ intervals for later analyses of grain size and composition. Although small variations in lithology occur laterally from core to core, a striking similarity in lithology and vertical changes in lithology are exhibited in all the cores examined. The sequence which partially fills the lake basin can be subdivided into six facies, all with gradational contacts. A complete marl bench sequence consists of four marl facies, two deposited on the inclined bench slope overlain by two deposited on the bench platform. These in turn are overlain by peat. In addition, bench slope units grade downward into a sixth facies deposited in deep water (Fig. 5).

Figure 6 is a typical core taken on the bench platform along the northern lake margin. It exhibits a complete marl bench sequence comprised of four calcareous lithologies. From the top down they are: 


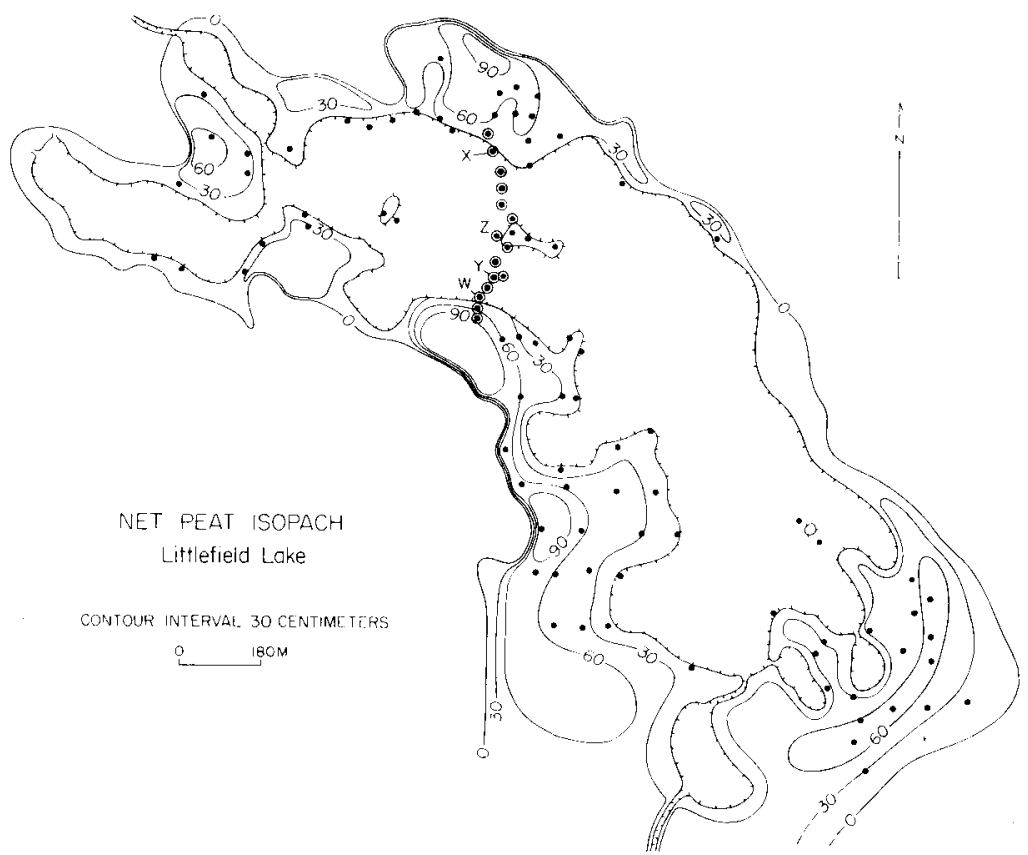

Fig. 3. Isopach map of peat overlying Littlefield Lake marl. Solid points from Davis (1903); circled points from this study. Cores $\mathrm{W}, \mathrm{X}, \mathrm{Y}$, and $\mathrm{Z}$ are identified in later figures.

N

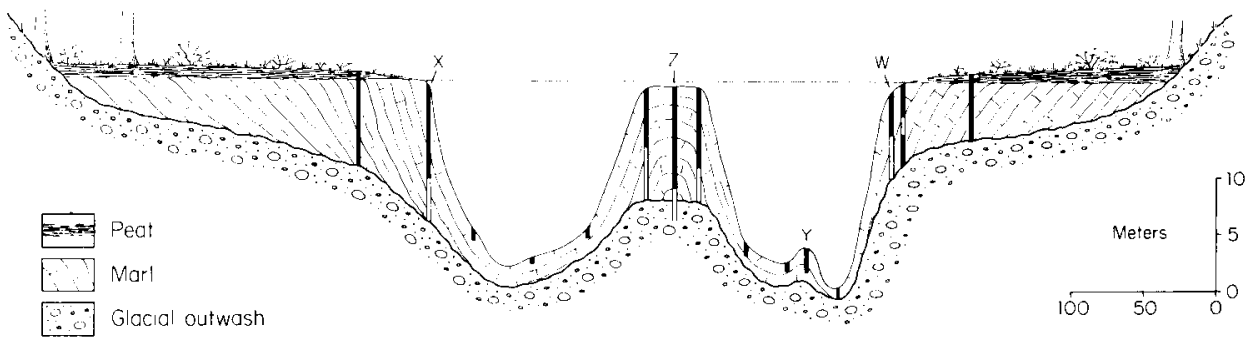

Fig. 4. North-south cross-section through Littlefield Lake. Solid bars designate recovered cores. Open bars designate sediment penetrated by washing down with drill pipe, recovering only resuspended sediment from these intervals. Note thicker sediment accumulation over the lakemounts and along lake margins. See Fig. 1 for section location. Cores $W$, $X, Y$, and $Z$ are identified in later figures.

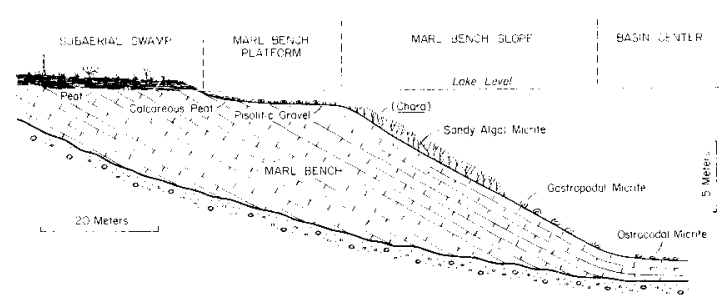

Fig. 5. Section across a typical nearshore area in Littlefield Lake showing the morphology of the marl bench and the distribution of modern facies.
Calcareous Peat, Pisolitic Gravel (both deposited on the shallow bench platform), Sandy Algal Micrite, and Gastropodal Micrite (both deposited on the inclined bench slope) (Figs 7 and 8 ).

\section{Bench platform units}

Calcareous peat facies

In a complete sequence this unit occurs as the upper of two bench platform facies and overlies pisolitic 


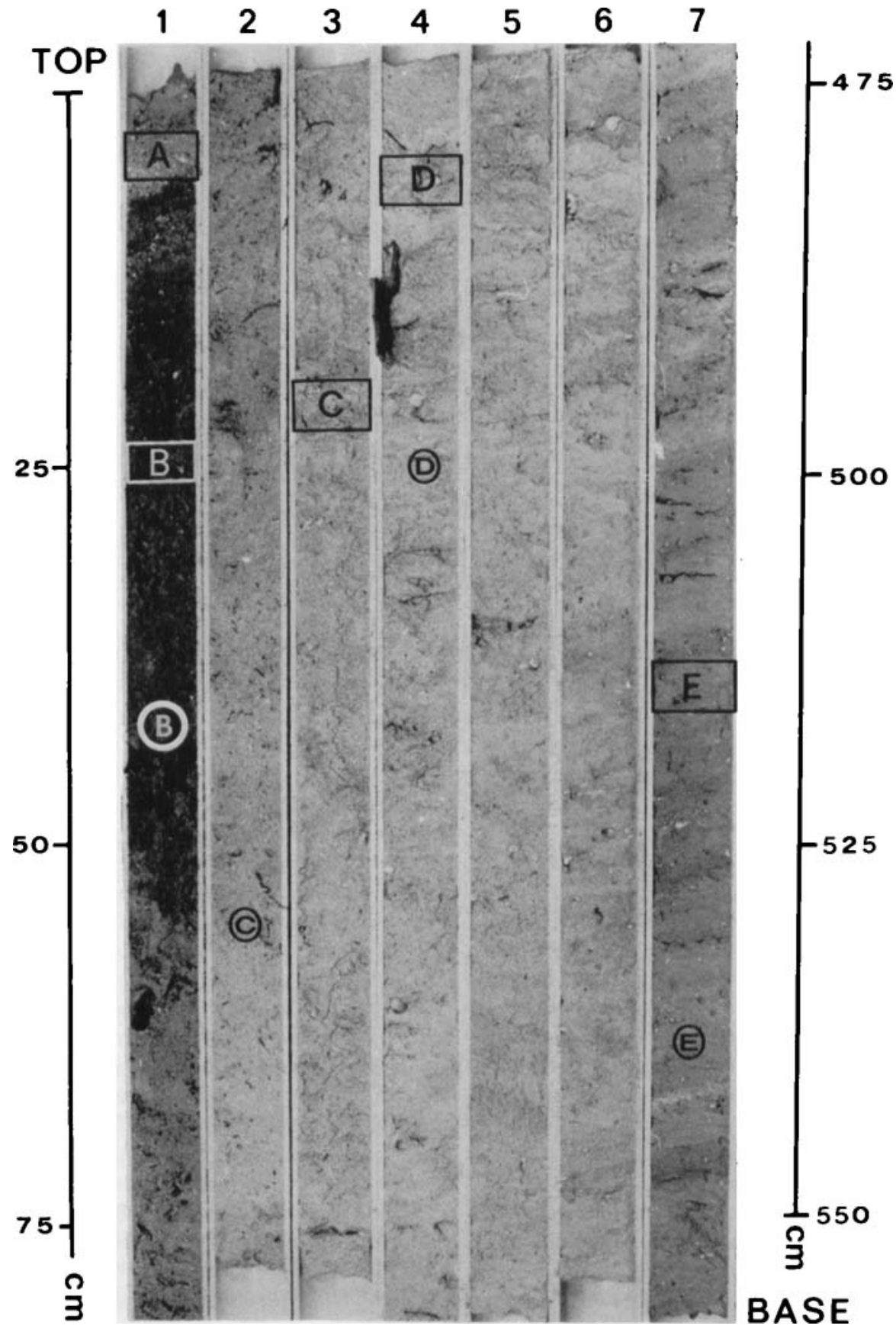

Fig. 6. Photograph of a typical marl bench sequence. This fixed-piston core was taken on the unvegetated bench platform along the northern lake margin. See Figs 2-4, core ' $X$ ' for location. Boxes A-E mark the positions of photographs in Fig. 7. Circles B-E mark the positions of thin-section photomicrographs in Fig. 8. Note the dark-coloured, organic-rich interval in Tube 1 grading into light-coloured marl in Tube 4, which in turn grades into darker, thinly laminated micrite in Tube 7. The thin lens of pisolitic gravel ' $A$ ' in this core, overlying calcareous peat ' $B$ ', is atypical for marl bench sequences. Thicker accumulations of pisolitic gravel normally underlie the CaJcareous Peat Facies. 

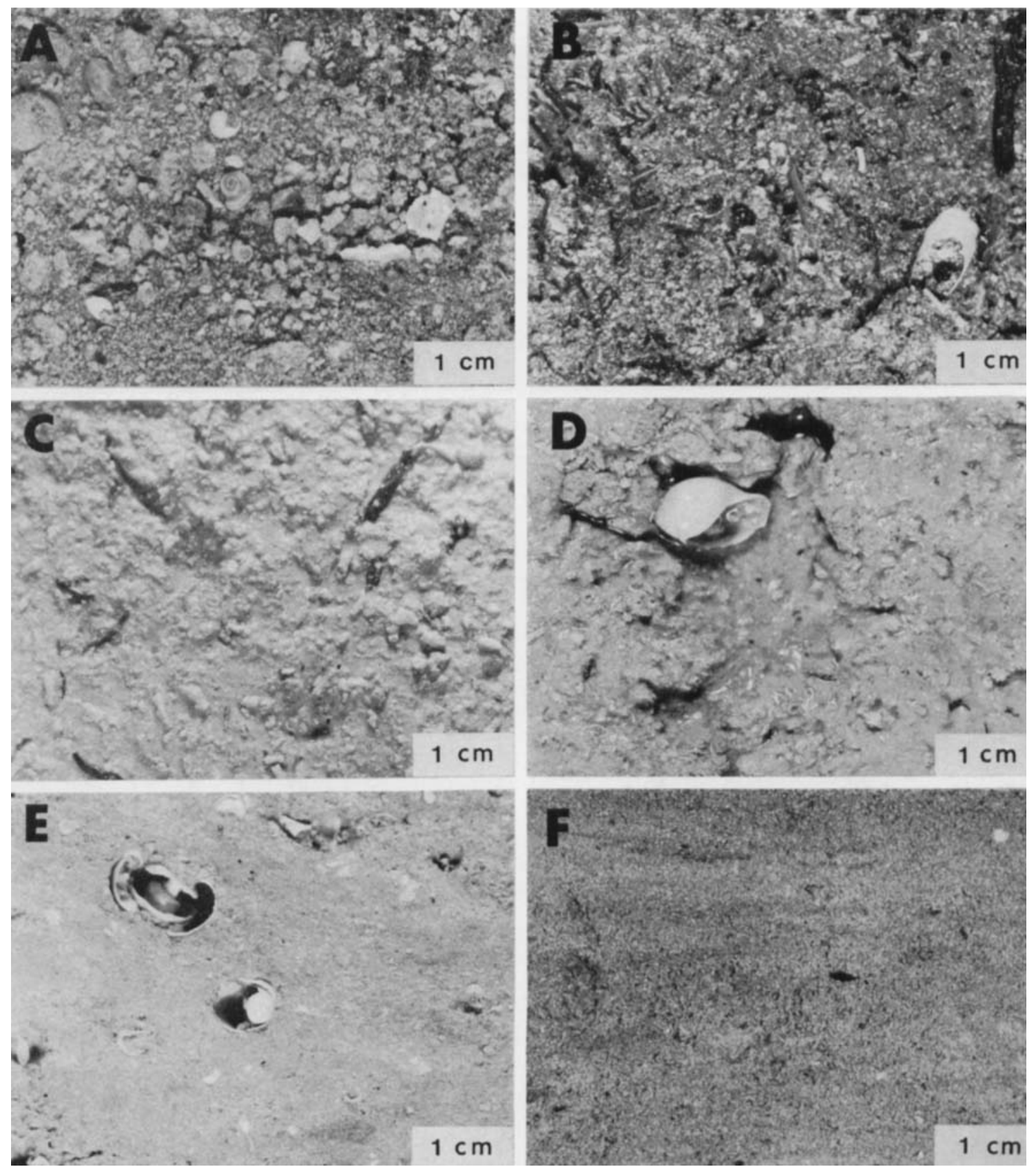

Fig. 7. Photographs of core ' $X$ ' (A-E) and core ' $Y$ ' (F). See Figs 2-4 for core locations. (A) Pisolitic gravel. This coarse carbonate is composed of blue-green algal pisoliths, gastropod debris, and sparse fragments of encrusted Chara. (B) Organic-rich marl deposited at the lower limit of the calcareous peat facies. In this sample, organic debris comprises about $20 \%$ of the sediment volume. The carbonate fraction consists of pisolith fragments, gastropods, and sparse encrusted Chara stems. (C) Sandy algal micrite containing abundant encrusted Chara stems and sparse organic debris. (D) Sandy algal micrite deposited in water approximately $80 \mathrm{~cm}$ deeper than $7 \mathrm{C}$. This interval is finer-grained, containing less Chara debris and considerably less plant material. (E) Thinly laminated gastropodal micrite containing sparse Chara, a few ostracods, and no macroscopic plant debris. Gastropods are the dominant faunal element of this facies. (F) Laminated ostracodal micrite deposited in the deep basin centre. The sandy appearance of this photograph is due to the higher pelleted nature of this facies. 

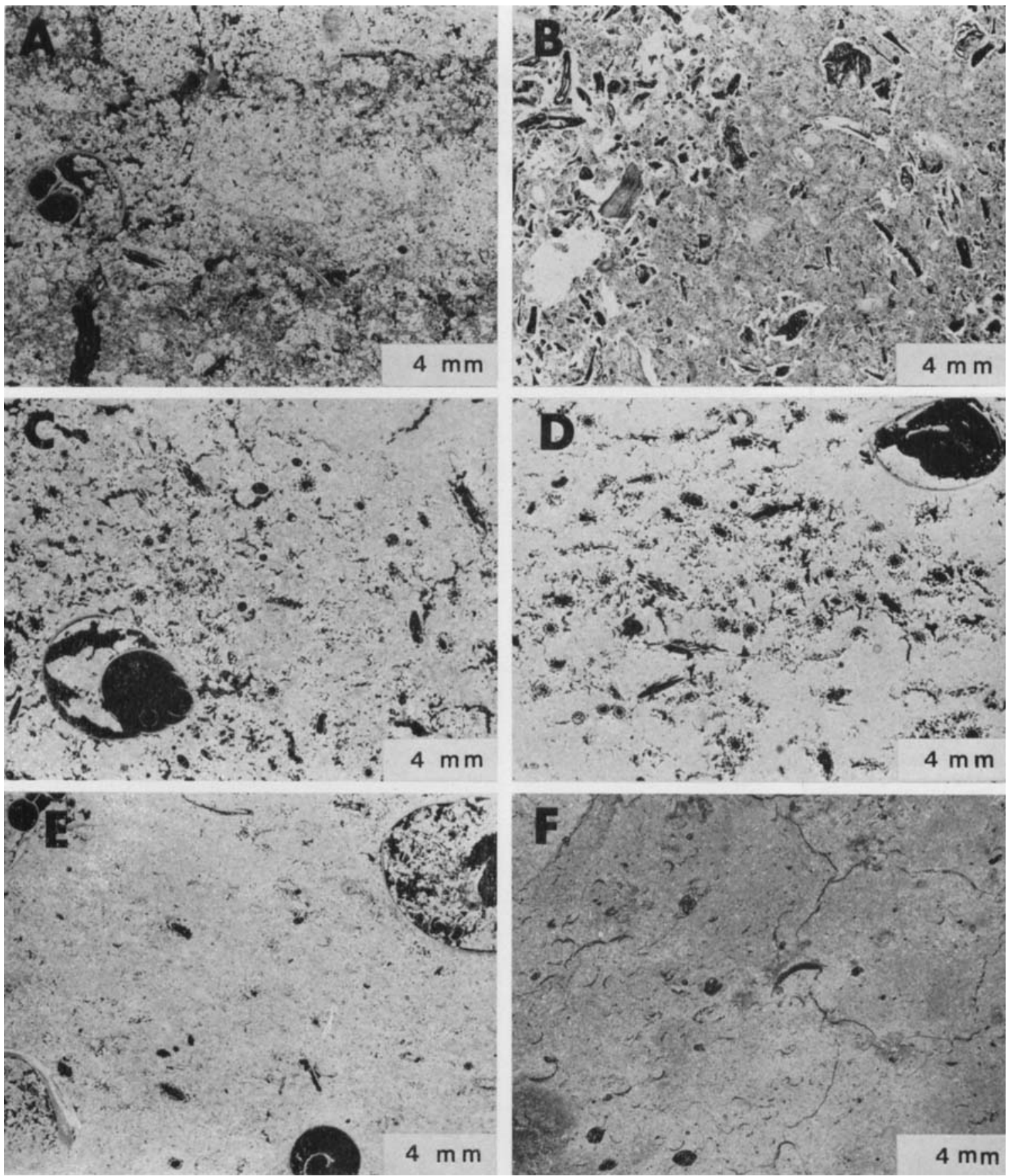

Fig. 8. Thin section photomicrographs of core 'W' (A), core ' $X$ ' (B-E), and core ' $Y$ ' (F). See Figs 2-4 for core locations. Polars are crossed in all photomicrographs except 8B. (A) Pisolitic gravel composed of gastropod debris, sparse encrusted Chara stems, and algal pisoliths which in this section appear as the large white irregular porous areas. (B) Organic-rich marl deposited at the lower limit of the calcareous peat facies. Note the light-coloured matrix and darker organic debris. (C) and (D) Sandy algal micrite. Abundant fragments of encrusted Chara stems make up the sand-size fraction within this facies. Also note sparse gastropods in both sections. (E) Gastropodal micrite. Note the near absence of fragments of encrusted Chara stems in this section, especially as compared with 8C and D. (F) Ostracodal micrite. Note the abundant articulated and disarticulated ostracods in this dark micritic matrix. These small crustaceans are the predominant faunal element of this facies. 
gravel. It is best developed along the northern lake margin where it attains a thickness of nearly $50 \mathrm{~cm}$. The sediment is a mixture of carbonate sand consisting predominately of pisolith debris, and plant and wood fragments (Figs 7B and 8B). In a perfectly developed interval this facies grades into pisolitic gravel at the bottom and into pure peat at the top. It is deposited at the landward edge of the bench platform as the latter becomes subaerially exposed and colonized by terrestrial plants (Fig. 5).

\section{Pisolitic gravel facies}

This unit occurs as the lowest and most extensive of two bench platform facies and is the dominant type of sediment being deposited on bench platforms in Littlefield Lake. It is a thin unit (up to $1.5 \mathrm{~m}$ ) composed of light tan to greyish white massive carbonate sand and gravel (Figs 7A and 8A). The gravel fraction is composed predominantly of whole pisoliths with a few large pisolith fragments (Jones \& Wilkinson, 1978). A small number of fragments of encrusted Chara also occur as sand-sized particles in this unit. An associated mud fraction occurs in subordinate quantities, as does sparse plant debris. This unit is occasionally rich in gastropods (Fig. 7A). Around marl islands where it is best developed, the concentration and size of whole pisoliths decreases downwards.

\section{Bench slope units}

Sandy algal micrite facies

This unit occurs as the upper of two facies deposited on the bench slope and overlies gastropodal micrite. Together the two slope facies make up the bulk of a marl bench sequence. This unit is a light-coloured, massive sandy micrite with sand-sized particles comprised mainly of fragments of encrusted Chara stems (Figs 7C, 7D, 8C and 8D). The concentration of these fragments decreases with depth. A few Chara oogonia are also found scattered throughout this interval. The lower limit of this unit is normally between 4 and $6 \mathrm{~m}$ below lake level, which probably marks the lower limit of Chara growth. Sparse gastropods and bivalves are also normally found, but plant debris is rare except in the upper portions. Occasionally this unit is partially laminated. Sandy algal micrites represent deposition on the upper portion of the bench slope where a thick stand of Chara grows in the summertime (Fig. 5).

Gastropodal micrite facies

In a complete sequence this unit occurs as the lower of the two bench slope facies. It is a medium grey to greenish grey, thinly laminated carbonate mud (Figs 7E and 8E). The small percentage of fine sand present is probably derived from shallower water deposits, perhaps during storms. The biota is dominated by gastropods, although a few bivalves and ostracods are also found, and is characterized by the near absence of fragments of encrusted Chara stems. This facies is deposited on the lower portions of the bench slope, probably below the photic zone, as evidenced by the near absence of Chara remains. A few small faults produced by slumping occur in cores through this interval. In the marl island and lake margin sequences this unit directly overlies Pleistocene drift where it attains a maximum thickness of $4 \mathrm{~m}$. Presumably this unit will attain somewhat greater thicknesses as the bench sequence progrades out over deep water deposits.

\section{Size and composition of marl bench deposits}

Grain-size analyses were done by wet sieving in order to quantify the changes in grain size with depth observed in marl bench sequences. All cores analysed from both lake margin areas and marl islands show coarsening-upward trends (Fig. 9). The gravel fraction is composed entirely of pisoliths and pisolith fragments. Downcore the sand fraction is principally fragments of encrusted Chara while, qualitatively, the mud fraction appears to be mainly silt. This coarsening-upward sequence is developed as a result of both mechanical sorting and primary production of carbonate sand and gravel at shallower depths.

Chemical analyses were done employing a loss on ignition method (Dean, 1974) in order to assess variations in marl composition with depth. In general, the weight percentage of noncombustible, insoluble material such as terrigenous clastics, and to a lesser extent the weight percentage of organic matter, increases with depth (Fig. 10). Conversely, the weight percentage of combustible carbonate decreases with depth. These trends probably reflect lower rates of carbonate sedimentation in deeper water. For organic and carbonate components, these trends are reversed only in samples immediately underlying the sediment surface. This reversal reflects both rapid decomposition of organic matter immediately after burial, and the influx of organic debris from surrounding swamps.

$\mathrm{X}$-ray analyses show the presence of pyrite in each of the marl bench facies. It is presumably authigenic 


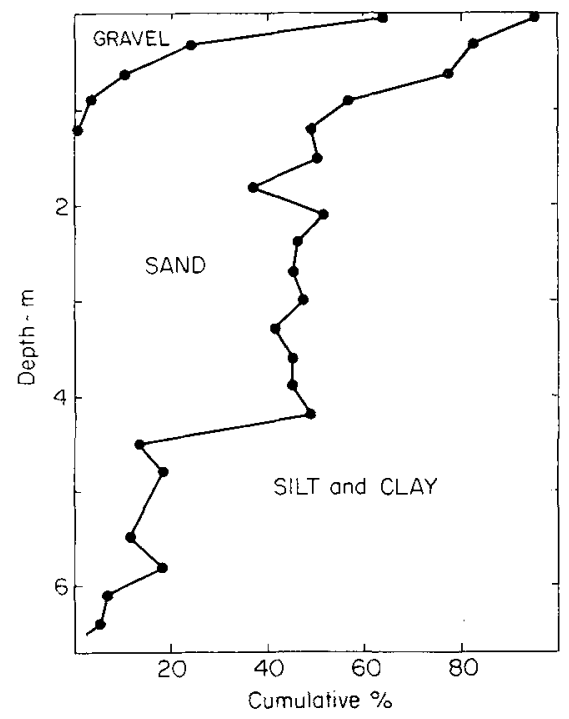

Fig. 9. Typical grain size versus depth curves for a marl bench sequence in Littlefield Lake. This is core ' $Z$ ' in Figs 2-4. The gravel-sand boundary is at $2.0 \mathrm{~mm}$ $(-1 \phi)$. The sand-mud boundary is at $0.0625 \mathrm{~mm}(4 \phi)$.

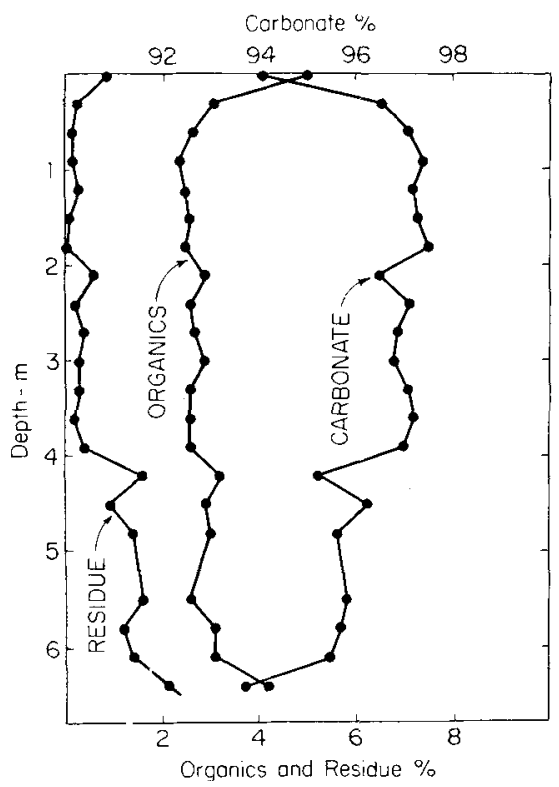

Fig. 10. Typical composition versus depth graph for a marl bench sequence in Littlefield Lake. This is core ' $Z$ ' in Figs 2-4. Organic matter is that fraction which is combustible at $550^{\circ} \mathrm{C}$ during a $2 \mathrm{~h}$ burn. Carbonate is that fraction which degasses $\mathrm{CO}_{2}$ at $1000^{\circ} \mathrm{C}$ during a $2 \mathrm{~h}$ burn. Residue is noncombustible material left after one of these runs. because of: (1) its sparse but ubiquitous occurrence, (2) the exceedingly small size of individual grains which are not discernible even in thin section, and (3) the absence of any terrigenous source for grains of this composition. Pyrite formation would be favoured in these organic-rich sediments, since decomposition of organic matter after burial probably soon produces anoxic conditions.

\section{Basin centre unit}

Ostracodal micrite facies

In a marl sequence this unit occurs as the lowermost facies, directly underlying and grading upward into gastropodal micrite. It is the only type of sediment currently being deposited below the thermocline in the deeper portions of Littlefield Lake. The sediment is a dark, greenish grey carbonate mud that is pelleted, laminated, and exhibits a high water content (Figs 6F and 7F). Qualitatively, the mud appears to be mainly clay-size particles. The fauna is composed almost completely of well preserved articulated and disarticulated ostracods. Compositional trends developing in the lower portions of lake margin and marl island cores are seen to continue into this deeper water facies. The weight percentage of noncombustible material increases to an average of $15-20 \%$, compared to $0 \cdot 5-2.5 \%$ in the marl bench units. Also, the weight percentage of combustible organic matter increases to an average of $10-15 \%$, in contrast to values between 2.5 and $4.5 \%$ for shallower facies. Concurrently, the weight percentage of combustible carbonate decreases to an average of $65-70 \%$. The large decrease in carbonate content from the $93-95 \%$ seen in the overlying gastropodal micrite probably reflects partial dissolution of carbonate minerals below the thermocline. X-ray analyses also show the presence of pyrite in this unit. Its presence indicates that anoxic conditions are also produced within these sediments soon after burial.

\section{DISCUSSION}

With retreat of the Wisconsin ice sheet from the area of Isabella County about 13,000 years ago, the Littlefield Lake kettle complex filled with water. Long cores through marl bench sequences indicate this flooding was both rapid and complete when the lake basin filled. Sediments found immediately overlying Pleistocene outwash indicate maximum 
water depths at the time of their deposition. Deposition began, and was most rapid, along the lake margins and on central high areas. Thicker marl deposits developed along lake margin areas and over lakemounts in the basin centre reflecting faster rates of carbonate production in shallower water. This greater rate of production, at least in part, is the result of partial disintegration of carbonate encrustations around Chara and other macrophytes growing in the photic zone, and blue-green algal pisoliths. The generation of carbonate might be augmented by physiochemical precipitation directly from near-surface lake water. A markedly thinner accumulation of marl in deep water is probably the result of both the absence of Chara as a sediment contributor, and partial dissolution of calcite below the thermocline.

With time, the marl bench sequence progrades basinward. Continued deposition should completely fill the lake, producing a lenticular, coarseningupward carbonate sequence. Rough calculations based upon past rates of carbonate production indicate the basin should fill completely in another 20,000 years.

A facies model for temperate region lacustrine carbonate systems can also be inferred from this

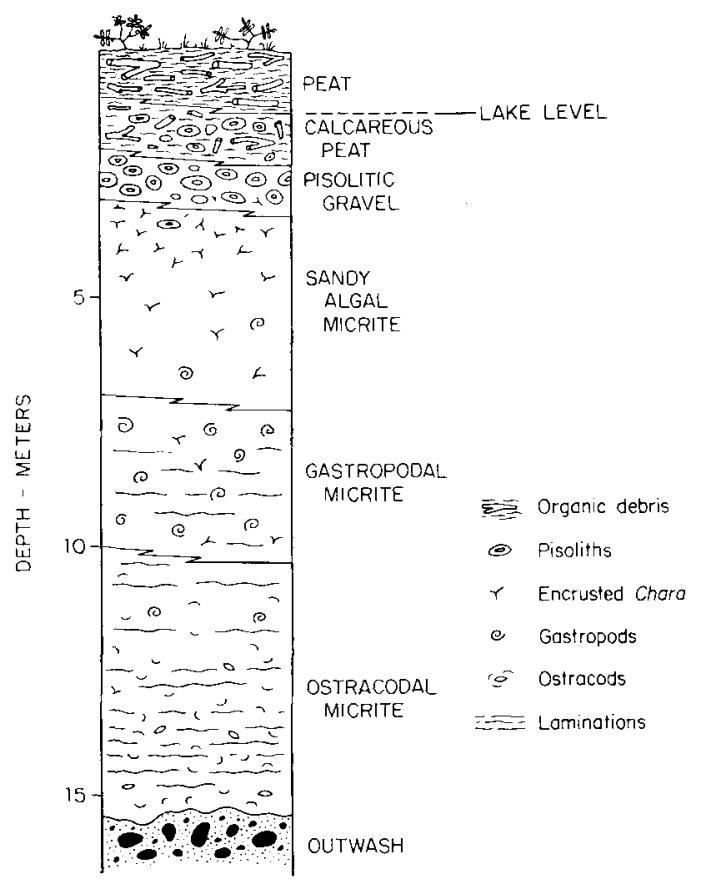

Fig. 11. Idealized stratigraphic column for temperateregion lacustrine carbonate deposits. study. A complete sequence is composed of six units: peat and five carbonate facies (Fig. 11). Ostracodal micrite is deposited in the cold, relatively stagnant portions of the lake basin as a result of particle settling in quiet waters of the hypolimnion. This sediment is derived from resuspension of finegrained material in shallow water by surface waves, and possibly from physiochemical precipitation of fine-grained calcite in the epilimnion. In a thick sequence this facies should comprise the bulk of the carbonate sediments. Gastropodal micrite is deposited on the lower portions of the bench slope in the area below the photic zone by processes similar to those which deposited ostracodal micrite. Laminations are well preserved in both of these facies because anoxic conditions, developed soon after burial, inhibit bioturbation. This and overlying bench facies prograde over ostracodal micrite as the marl bench builds out toward the lake centre.

Sandy algal micrite is deposited on the upper portion of the bench slope, an area overgrown by thick stands of Chara which become thickly encrusted with calcite in the summertime. Partial disintegration of these encrustations produces fine sediment, most of which is deposited in situ. Pisolitic gravel forms on the flat bench platform in very shallow water. This sediment is composed predominantly of whole pisoliths and pisolith fragments.

Calcareous peat, deposited on the landward edge of the bench platform, grades into both underlying pisolitic gravel and overlying peat which is deposited just above lake level (Fig. 11). As water depth decreases with marl deposition, the bench platform is colonized by terrestrial plants which progressively deposit more organic debris on the landward edge of the now vegetated bench. Thinner, more landward portions of the sequence exhibit only shallower marl facies. As the sequence thins towards its margins, deeper units successively pinch out, with only pisolitic platform units being present at the edge of the sequence.

This model can be used to interpret ancient carbonate sequences deposited under similar conditions. In the case of temperate-region lakes, glacial drift is the main source of calcium carbonate. However, similar carbonate-precipitating lacustrine systems will develop in terrigenous basins where: (1) climates are sufficiently seasonal that calcite precipitation occurs during warmer months, and (2) the lithology of the watershed is such that inflowing water is saturated with calcium carbonate. 
At this time it is difficult to ascertain the volumetric importance of similar sequences in the rock record owing to a lack of sufficient data on potentially analogous systems. Numerous ancient lacustrine limestones occur as component facies within terrigenous clastic sequences where older carbonate rock fragments are an important clast type. These lacustrine sequences possess pisolitic intervals, exhibit faunas similar to those in temperate-region systems, and lack those features which indicate deposition in evaporitic playa settings. Should these be ancient analogues to temperate-region marl basins such as Littlefield Lake, fairly specific inferences could be made regarding the mechanisms responsible for their formation and the climatic conditions under which they were deposited. Facies distributions in Littlefield Lake serve as a model against which vertical trends observed in ancient lacustrine carbonates may be evaluated.

\section{CONCLUSIONS}

(1) Progradational marl bench sequences constitute a large portion of temperate-region lacustrine carbonate deposits. These result from carbonate formation in shallow water, primarily through biochemical precipitation associated with the photosynthetic activity of macrophytes, primarily Chara.

(2) Vertical bench sequences are nearly identical to lateral facies being deposited on the lake bottom and are characterized by an upward increase in lowmagnesian calcite and downward increases in both organic material and non-combustible components. These trends are reversed only at the top of the bench, where peat progrades basinward over exposed bench platforms.

(3) Coarsening-upward sequences and facies distributions similar to those exhibited in the Littlefield Lake complex serve as a model for temperateregion carbonate systems in general, against which trends observed in lacustrine limestones can be compared when attempting palaeoenvironmental reconstructions of ancient lake environments.

\section{ACKNOWLEDGMENTS}

We would like to thank Walter Dean (U.S.G.S.), Louis I. Briggs (The University of Michigan) and C. I. Smith (The University of Texas-Arlington) for reading the original manuscript and making helpful suggestions. Portions of this study were supported from a Scott Turner Earth Sciences Award from the Department of Geology and Mineralology. The assistance of Cyinthia Glass, Joan Pollock, Katherine Pattridge, Steven Glass, Bernard Coakley, and Kathy Binkley during field work and manuscript preparation is gratefully acknowledged. Drafting was done by Derwin Bell. Research at The University of Michigan on recent lacustrine carbonates is supported by the Division of Earth Sciences National Science Foundation, NSF Grant EAR78-03634.

\section{REFERENCES}

Blatchley, W.A. \& Ashley, G.H. (1900) The lakes of Northern Indiana and their associated marl deposits. Ann. Rep. Indiana Dept Geol. Nat. Res. 31-52.

Brunskill, G. (1968) Fayetteville Green Lake, New York. I. Physical and chemical limnology; II. Precipitation and sedimentation of calcite in a meromictic lake with laminated sediments. Unpublished Ph.D. Thesis, Cornell University, $171 \mathrm{p}$.

DAvis, C.A. (1900) A contribution to the natural history of marl. J. Geol. 9, 485-497.

DAvis, C.A. (1901) A second contribution to the natural history of marl. J. Geol. 10, 491-497.

Davis, C.A. (1903) Contribution to the natural history of marl. Rep. geol. Surv. Mich. 8, 65-99.

DEAN, W.E., Jr (1974) Determination of carbonate and organic matter in calcareous sediments and sedimentary rocks by loss on ignition: comparison with other methods. J. sedim. Petrol. 44, 242-248.

Eugster, H.P. \& Hardie, L.A. (1975) Sedimentation in an ancient playa-lake complex; the Wilkins Peak Member of the Green River Formation of Wyoming. Bull. geol. Soc. Am. 86, 319-334.

Eugster, H.P. \& SurdaM, R.C. (1973) Depositional environment of the Green River Formation of Wyoming: a preliminary report. Bull. geol. Soc. Am. 84, $1115-1120$.

FETH, J.H. (1964) Review and annotated bibliography of ancient lake deposits (Precambrian to Pleistocene) in the Western United States. Bull. U.S. geol. Surv. $1080,119 \mathrm{p}$.

Hooper, F. (1956) Some chemical and morphometric characteristics of Southern Michigan lakes. Mich. Acad. Sci. Arts Letts, 51, 109-130.

INSTITUTE FOR FISHERIES RESEARCH (1950) Littlefield Lake survey. Unpublished data, Michigan Department of Conservation, $20 \mathrm{p}$.

JoNes, F.G. \& WILKINSON, B.H. (1978) Structure and growth of lacustrine pisoliths from Recent Michigan marl lakes. J. sedim. Petrol. 48, 1103-1110.

KeRr, J.A. \& TruLl, F.W. (1928) Soil survey Isabella County Michigan. U.S. Dept Agric. Ser. 1923, No. $36,1183-1202$.

KINDLE, E.M. (1927) The role of thermal stratification in lacustrine sedimentation. Trans. $R$. Soc. Canada, Ser. 3, No. 21, 1-36. 
Kindie, E.M. (1929) A comparative study of different types of thermal stratification in lakes and their influence on the formation of marl. J. Geol. 37, 150-157.

Marsh, W.M. \& Borton, T.E. (1974) Michigan Inland Lakes and Their Watersheds: An Atlas. Michigan Department of Natural Research, $166 \mathrm{p}$.

Pollock, J.B. (1918) Blue-green algae as agents in the deposition of marl in Michigan lakes: Mich. Acad. Sci. Arts Letts, 20, 247-260.

Surdam. R.C. \& Wolfbauer, C.A. (1975) Green River
Formation, Wyoming: a playa lake complex. Bull. geol. Soc. Am. 86, 335-345.

Terlecky, P.M., Jr (1974) The origin of a late Pleistocene and Holocene marl deposit. J. sedim. Petrol. 44, $456-465$.

WetZEL, R.G. (1960) Marl encrustration on hydrophytes in several Michigan lakes. Oikos, 11, 223-236.

Wolfbauer, C.A. \& Surdam, R.C. (1974) Origin of non-marine dolomite in Eocene Lake Gosiute, Green River Basin, Wyoming. Bull. geol. Soc. Am. 85, 1733-1740.

(Manuscript received 27 November 1978, revision received 10 April 1979) 